\title{
HISTOLOGICAL EXAMINATION OF SEROSAL MEMBRANES IN STUDIES OF EARLY EMBRYONIC MORTALITY IN THE EWE
}

\author{
D. P. BOSHIER \\ Department of Veterinary Biology, Massey University, \\ Palmerston North, New Zealand \\ (Received 15th November 1966, revised 18th Fanuary 1967)
}

\begin{abstract}
Summary. Histological examination of sheep extra-embryonic membranes obtained 18 days post coitum permitted more precise assessment of embryonic viability than did reliance on the macroscopic appearance of the embryo. Thirteen of twenty-seven sets of membranes examined had contained embryos which, although within the normal development range, were of doubtful viability. These thirteen sets of serosal membranes were found histologically to fall into one of two groups. Seven specimens were similar to seven sets of membranes in which a living embryo had been found, while six sets paralleled the remaining degenerating membranes in which there was no recognizable embryo. Histological features of the normal and degenerating serosal membranes are described.
\end{abstract}

\section{INTRODUCTION}

By the 18th day of gestation in the ewe, the early bilaminar omphalopleure of the embryo has given way to a bilaminar somatopleure with which the vascularized allantois has not yet made anatomical contact (Assheton, 1906). Before implantation, death of the embryo or the extra-embryonic membranes will result in the death of all embryonic tissues. Consequently, histological examination of either of those elements should permit an evaluation of conceptus viability.

This communication reports histological investigations of extra-embryonic membranes, embryos and uteri from ewes slaughtered 18 days post coitum (p.c.). Because the serosal membranes associated with embryos of known viability had a characteristic histological picture, it was decided that specific features of the membranes could be assessed sufficiently well to form the basis of an arbitrary scoring system. Embryonic membranes, in which a morphologically normal embryo showing regular cardiac contractions was found, were histologically similar to those figured by Amoroso (1952) and were defined as living. Those membranes in which no embryo was present, however, had undergone vacuolar degeneration (Robbins, 1962) and were defined as dead. It is suggested that histological examination of serosal membranes associated with embryos known to be alive or dead may help in defining embryonic viability in investigations of 
prenatal mortality. No similar studies in domestic animals appear to have been reported.

\section{MATERIALS AND METHODS}

A total of 183 sets of extra-embryonic membranes were recovered from 127 New Zealand Romney ewes slaughtered 18 days p.c. and were examined within 30 min of the dams' death. Details of the animals slaughtered, the manner in which the embryos were recovered and the criteria for gross determination and classification of embryonic viability have been given by Quinlivan, Martin, Taylor \& Cairney (1966). Of the 156 embryos found within the serosal membranes, 143 were alive, i.e. anatomically normal and showing regular cardiac contractions. The remaining thirteen were macroscopically normal, but of doubtful viability, because the heart did not contract when the embryo was physically stimulated in a bath of warm normal saline. These thirteen specimens

TABLE 1

SCHEME BY WHICH TOTAL HISTOLOGY SCORE FOR EXTRA-EMBRYONIC MEMBRANES WAS DETERMINED AFTER EVALUATION OF SPEGIFIC FEATURES OF THE SEROSAE

\begin{tabular}{|c|c|c|c|}
\hline \multirow{2}{*}{$\begin{array}{c}\text { Trophoblast } \\
\text { feature assessed }\end{array}$} & \multicolumn{3}{|c|}{ Score } \\
\hline & 0 & 1 & 2 \\
\hline Nucleus & Pycnotic & $\begin{array}{l}\text { Homogeneously } \\
\text { darkly stained }\end{array}$ & Normal \\
\hline Cytoplasm & $\begin{array}{l}\text { Few large clear } \\
\text { vesicles }\end{array}$ & $\begin{array}{l}\text { Numerous small } \\
\text { clear vesicles }\end{array}$ & Normal \\
\hline $\begin{array}{l}\text { Trophoblast mesoderm } \\
\text { association }\end{array}$ & Separated & $\begin{array}{l}\text { Some } \\
\text { dissociation }\end{array}$ & $\begin{array}{l}\text { No } \\
\text { dissociation }\end{array}$ \\
\hline No. of binucleate cells* & $0-0.9$ & $1-45$ & $>46$ \\
\hline No. of mitoses* & $0-0.9$ & $1-20$ & $>21$ \\
\hline $\begin{array}{l}\text { No. of cells containing } \\
\text { Stäbchen*† }\end{array}$ & $0-0.9$ & $1-350$ & $>351$ \\
\hline
\end{tabular}

* Averages of counts made in fifteen serial sections, using coincident fields which were $650 \mu$ long and typical of the specimen.

$\dagger$ 'Uterinstäbchen' of Bonnet (see Amoroso, 1952).

of embryonic tissues (embryo and/or its extra-embryonic membranes) were examined histologically, together with seven sets of serosal membranes that had contained a living embryo and seven sets in which no embryo could be identified. Eleven associated uteri were similarly examined.

All tissues were fixed in $10 \%$ formalin, embedded in paraffin wax and then 5- to 6- $\mu$ thick sections of the serosal membranes, embryos and uteri were stained with haematoxylin and eosin. Five or more sections of each embryonic or uterine specimen were examined microscopically and the tissues were assessed as histologically normal or abnormal. The normal condition was that characteristic of embryos known to have been alive, and of lesion-free uteri from which such embryos had been obtained; abnormal tissues were those not having equivalent histological appearance. The serosal membranes were evaluated according to a scheme which allowed each of six histological features character- 
istic of 18-day sheep extra-embryonic membranes to be scored (Table 1), the total histology score being the sum of these six individual scores (Table 2).

\section{RESULTS}

Embryonic tissues

The normal 18-day sheep trophoblast is a pseudo-stratified epithelium lined internally by a thin unicellular layer of somatic mesoderm (Pl. 1, Fig. 1 and Pl. 2, Fig. 5). The majority of the trophoblast cells, already in close contact with

TABLE 2

CLASSIFICATION AND HISTOLOGICAL RECORD OF 18-DAY EXTRA-EMBRYONIC MEMBRANES ILLUSTRATING MANNER IN WHIGH SCORES OBTAINED LOCATED MEMBRANES IN TWO GLASSES PARALLELING SEROSAE OF DEFINED VIABILITY

\begin{tabular}{|c|c|c|c|c|c|c|c|}
\hline $\begin{array}{l}\text { Ewe } \\
\text { No. }\end{array}$ & $\begin{array}{c}\text { Survey } \\
\text { classification }^{\mathrm{a}}\end{array}$ & $\begin{array}{c}\text { Total } \\
\text { histology } \\
\text { score }^{\mathrm{b}}\end{array}$ & $\begin{array}{c}\text { Tissue } \\
\text { character }\end{array}$ & $\begin{array}{c}\text { Survey } \\
\text { classification }\end{array}$ & $\begin{array}{c}\text { Total } \\
\text { histology } \\
\text { score }\end{array}$ & $\begin{array}{c}\text { Tissue } \\
\text { character }\end{array}$ & Uterus $^{\mathrm{d}}$ \\
\hline $\begin{array}{l}\text { SINGLE EMBRYO } \\
\text { B43 } \\
\text { B10 } \\
\text { B527 } \\
\text { B555 } \\
\text { B575 } \\
\text { B562 } \\
\text { B74 } \\
\text { B512 }\end{array}$ & $\begin{array}{l}\mathrm{A}_{2} \\
\mathrm{~A}_{3} \\
\mathrm{~A}_{3} \\
\mathrm{~A}_{3} \\
\mathrm{~A}_{3} \\
\mathrm{~A}_{3} \\
\mathrm{~A}_{3} \\
\mathrm{~B}_{3}\end{array}$ & $\begin{array}{r}9.2 \\
11.4 \\
10 \cdot 8 \\
10.5 \\
10 \cdot 2 \\
6.1 \\
3.1 \\
5 \cdot 0\end{array}$ & $\begin{array}{l}\text { V } \\
\text { V } \\
\text { V } \\
\text { V } \\
\text { V } \\
D \\
D \\
D\end{array}$ & & & & $\begin{array}{l}\text { NA } \\
\text { N } \\
\text { NA } \\
\text { N } \\
\text { N } \\
\text { NA } \\
\text { Abn } \\
\text { NA }\end{array}$ \\
\hline $\begin{array}{l}\text { TWIN EMBRYos } \\
\text { B55 } \\
\text { B540 } \\
\text { B564 } \\
\text { B31 } \\
\text { B574 } \\
\text { B79 } \\
\text { B80 } \\
\text { B26 } \\
\text { B542 } \\
\text { B53 }\end{array}$ & $\begin{array}{l}\mathrm{A}_{1} \\
\mathrm{~A}_{1} \\
\mathrm{~A}_{1} \\
\mathrm{~A}_{2} \\
\mathrm{~A}_{2} \\
\mathrm{~A}_{2} \\
\mathrm{~A}_{2} \\
\mathrm{~A}_{3} \\
\mathrm{~A}_{3} \\
\mathrm{~A}_{3}\end{array}$ & $\begin{array}{r}9 \cdot 2 \\
7 \cdot 0 \\
7 \cdot 0 \\
- \\
10 \cdot 9 \\
8 \cdot 3 \\
8 \cdot 3 \\
5 \cdot 2 \\
4 \cdot 2 \\
4 \cdot 1\end{array}$ & $\begin{array}{l}\text { V } \\
V \\
\text { V } \\
\mathrm{V}^{*} \\
\mathrm{~V} \\
\mathrm{~V} \\
\mathrm{~V} \\
\mathrm{D} \\
\mathrm{D} \\
\mathrm{D}\end{array}$ & $\begin{array}{l}\mathrm{B} \\
\mathrm{A}_{3} \\
\mathrm{~B} \\
\mathrm{~A}_{3} \\
\mathrm{~A}_{3} \\
\mathrm{~A}_{3} \\
\mathbf{B} \\
\mathrm{B} \\
\mathrm{B} \\
\mathrm{B}\end{array}$ & $\begin{array}{r}5 \cdot 5 \\
3 \cdot 6 \\
5 \cdot 3 \\
10 \cdot 7 \\
7 \cdot 1 \\
6 \cdot 6 \\
5 \cdot 9 \\
4 \cdot 7 \\
4 \cdot 6 \\
4 \cdot 9\end{array}$ & $\begin{array}{l}\text { D } \\
D \\
D \\
\text { V } \\
\text { V } \\
\text { V } \\
D \\
D \\
D \\
D\end{array}$ & $\begin{array}{l}\text { NA } \\
\text { N } \\
\text { NA } \\
\text { N } \\
\text { N } \\
\text { N } \\
\text { NA } \\
\text { Abn } \\
\text { N } \\
\text { N }\end{array}$ \\
\hline
\end{tabular}

a Classification used by Quinlivan et al. (1966)

$A_{1}=$ Anatomically normal and heart beating on recovery

$\mathrm{A}_{2}=$ Anatomically normal and heart contractions after stimulation $\}$ (defined as living).

$\mathrm{A}_{3}=$ Anatomically normal and no heart contractions after stimulation.

$\mathbf{B}=$ Extra-embryonic membranes only recognisable (defined as dead).

b Average total score obtained in six features of Table 1.

c $\mathrm{V}=$ Viable, $\mathrm{D}=$ dead, $*$ = embryo only.

d $\mathrm{N}=$ Normal, $\mathrm{Abn}=$ abnormal, $\mathrm{NA}=$ not available.

caruncles of the uterine horn in which the embryo was developing contained numerous eosinophilic Stäbchen. The trophoblastic binucleate cells constituted no more than 1 or $2 \%$ of the total trophoblast cell population, although they were found occasionally at higher concentration in localized groups.

In contrast, the serosal membranes recovered at 18 days p.c. which did not contain an embryo showed typical degenerative features (PI. 1, Fig. 4). The cell nuclei were pycnotic and the cytoplasm contained large clear vesicles, while the trophoblastic Stäbchen were considerably reduced in number and clarity. The bi-nucleate cells were not easily distinguished and there was considerable separation of the mesoderm cells from the trophoblast. 
A comparison of these two groups of serosal tissues defined as living or dead, i.e. those containing either a living embryo or no living material, allowed separation of the doubtfully viable specimens into viable or non-viable categories (Table 2). The serosal membranes of embryos known to have been alive when the dam was killed all scored above 7.0 (mean score $=8.56 \pm 0.43$ ), whereas 5.9 was the maximum score (mean score $=5 \cdot 13 \pm 0 \cdot 26$ ) for serosal membranes in which resorption or maceration of the embryo did not permit its recognition. These two groups were obviously different. If we calculate a point such that any observation below it would be significantly different from the mean of the living sample at the $5 \%$ level of probability, we find that the membranes scoring above 6.11 are not dead. However, the low numbers in the living $(n=7)$ and dead $(n=7)$ classes may reduce the validity of the standard deviation $(0.46)$ of the dead group. Consequently, the calculations are more efficient in distinguishing high scoring membranes as living than in distinguishing low scoring membranes as dead. Nevertheless, the biological evidence in those very low scoring specimens bears witness of their death. As a result of these comparisons, seven of the specimens of doubtful viability were judged to have been alive and the remaining six to have been dead when the dam was killed (Pl. 1, Figs. 2 and 3).

When the ewes were slaughtered, both embryos were alive in only three of the ten sets of twins examined, compared with the five living embryos taken from the eight ewes in which there were single sets of extra-embryonic membranes. Of the ten sets of twin extra-embryonic membranes considered, four contained only one living embryo, and in the remaining three sets no living embryos were present.

\section{Uterine tissues}

The uterine epithelium overlying the caruncles was lost in all the eleven uteri examined; the basement membrane and caruncular stroma were abnormal in two uteri (Pl. 2, Figs. 7 and 8, cf. Pl. 2, Figs. 5 and 6). In these two uteri, loss of the integrity of the basement membrane and of the stromal connective tissue in the central area of a number of the caruncles were associated with some lymphocytic infiltration (Pl. 2, Fig. 8). The embryos taken from the two uteri were all dead (B74, B 26; Table 2).

\section{DISCUSSION}

The manner in which the two groups of extra-embryonic membranes, which had or had not contained living embryos, separated themselves into the two distinct classes of histologically normal or degenerated tissues, demonstrated that the viability of the embryo was reflected in the histological state of the membranes. Thus, histological examination of extra-embryonic membranes and embryos of known viability provided a standard for evaluation of the viability of embryonic tissues of the same species which should have been at the same developmental stage.

Pre-implantation mortality is known to be of considerable significance in both polytocous and monotocous animals (Adams, 1959; Hanly, 1961; Boshier, 1964; Boyd, 1965). The data presented here, and by other workers (Moore, 
Rowson \& Short, 1960; Quinlivan et al., 1966) demonstrated that a similar state exists in the ewe. Moore et al. (1960), after using general embryonic appearance and a series of anatomical measurements as the basis of a classification scheme in their studies of 17- and 18-day sheep embryo viability, concluded that "it was very difficult to determine whether these retarded embryos were in fact alive or dead at the time of autopsy". The presence of seven sets of normal embryonic tissues in the sample of thirteen macroscopically normal but apparently lifeless specimens investigated, emphasized the necessity for gathering supplementary evidence when the viability of embryonic material was in doubt. Although the embryos present in these thirteen specimens were within the developmental ranges characteristic of an 18-day gestation, their serosal membranes fell into two distinct groups. In the first group, tissues similar to viable controls were seen. High numbers of normal epithelial cells containing Stäbchen and numerous cells in mitosis were present. In contrast, the second group showed typical degenerative changes in altered cell form, loss or modification of the Stäbchen and greatly reduced numbers of visible mitotic figures. Histological techniques have allowed more precise definition of levels of embryonic mortality than was possible with simple direct observation of embryos or uteri.

At the present state of knowledge, however, in most mammalian species it is not possible to judge, using histological techniques, how long an embryo, or its extra-embryonic membranes, has been dead. In analyses of foetal maceration in the rabbit, Shanklin, Cimino \& Lamb (1964) demonstrated histologically the rapidity with which degenerative changes occurred in various foetal tissues. A similar series of controlled experiments is needed in the domestic animals if the time lapse between death of the conceptus and its recovery is to be determined accurately.

The data obtained in both this and the parent study (Quinlivan et al., 1966) suggested that the presence of two embryos within the uterine tract prejudiced normal development and lowered the probability of their both persisting. Of the ten ewes with two sets of extra-embryonic membranes present within their uteri examined here, only three were found to contain two viable embryos. This is of interest in the light of Henning's (1939) report that in the ewe, the likelihood of all embryos remaining alive decreases as the number of corpora lutea increases. It does not, however, support Dutt's (1954) contention that ewes with twins possess a better uterine environment as a result of the increased hormone levels associated with two ovulations. The high fertility rates desirable in ewe flocks are dependent mainly on the birth of high numbers of live twin lambs. It is a feature of New Zealand conditions that more Romney ewes (41.05\% of 8432 stud ewes considered in 1963 to 1964; Quinlivan et al., unpublished data) give birth to live twin lambs than do the ewes of the breed from which they were originally developed $(33.6 \%$ of 316 ewes: Nichols, 1926 ; $31 \%$ of 8481 ewes: Thomson \& Aitken, 1959).

\section{ACKNOWLEDGMENTS}

I am grateful to $\mathrm{Mr} \mathrm{T}$. D. Quinlivan for providing the material for examination, to the members of the New Zealand Romney Breeders' Association for their assistance, to Miss P. M. Bain for the preparation of histological sections, and 
to $\mathrm{Mr}$ A. C. Glenday for assistance in the statistical considerations. I am grateful also to my colleagues who have kindly read and commented on the manuscript.

\section{REFERENCES}

ADAms, C. E. (1959) Studies on pre-natal mortality in the rabbit, Oryctolagus cuniculus: The amount and distribution of loss before and after implantation. 7. Endocr. 19, 325.

Amoroso, E. C. (1952) Placentation. In: Marshall's Physiology of Reproduction, 3rd edn, p. 195. Ed. A. S. Parkes. Longmans Green, London.

Assheton, R. (1906) The morphology of the ungulate placenta, particularly the development of that organ in the sheep, and notes upon the placenta of the elephant and hyrax. Phil. Trans. B, 198, 143.

Boshier, D. P. (1964) Some analyses of reproductive performance in inbred mice and their progeny. Diss. Abstr. 24, 9.

Boyd, H. (1965) Embryonic death in cattle, sheep and pigs. Vet. Bull., Weybridge, 35, 251.

Dutr, R. H. (1954) Fertility rate and embryonic death loss in ewes early in the breeding season. $\mathcal{F}$. Anim. Sci. 13, 464.

Hanky, S. (1961) Prenatal mortality in farm animals. F. Reprod. Fert. 2, 182.

Henning, W. L. (1939) Pre-natal and post-natal sex ratio in sheep. F. agric. Res. 58, 565.

Moore, N. W., Rowson, L. E. A. \& ShORT, R. V. (1960) Egg transfer in sheep. Factors affecting survival and development of transferred eggs. F. Reprod. Fert. 1, 332.

Nichols, J. E. (1926) Fertility in sheep. J. Minist. Agric. Fish. 33, 218.

Quinitivan, T. D., Martin, C. A., Taylor, W. B. \& Cairney, I. M. (1966) Estimates of pre- and perinatal mortality in the New Zealand Romney Marsh ewe. I. Pre- and peri-natal mortality in those ewes that conceived to one service. 7 . Reprod. Fert. 11, 379.

Robrins, S. L. (1962) Textbook of pathology with clinical application, 2nd edn, p. 105. Saunders, London.

Shankzin, D. R., Cimino, D. A. \& LAmB, T. H. (1964) Fetal maceration. I. An experimental sequence in the rabbit. Am. 7. Obst. Gynec. 88, 213.

Thomson, W. \& Artken, F. C. (1959) Diet in relation to reproduction and the viability of the young. Part II. Sheep: World survey on reproduction and review of feeding experiments. Tech. Comm. No. 20, p. 47. Commonwealth Agricultural Bureaux, Slough.

\section{EXPLANATION OF PLATES}

\section{PLATE 1}

Fig. 1. Section of detached normal 18-day serosal membranes showing trophoblast containing binucleate cells, Stäbchen, cell in mitosis, and lined internally by somatic mesoderm. $\times 300$ approx.

FIG. 2. Section of serosal membranes considered to be of doubtful viability, but classified as live on the death of the dam. $\times 300$ approx.

Fig. 3. Section of serosal membranes of doubtful viability classified as dead on maternal death. The cells are degenerated, sparse and have pycnotic nuclei. $\times 300$ approx.

Fig. 4. Section of low-scoring extra-embryonic membranes in which no embryo could be found. Considerable cell degeneration and separation of the membranes is apparent. $\times 300$ approx.

\section{PLATE 2}

Fig. 5. Normal 18-day serosal membranes in contact with uterine epithelium. $\times 300$ approx. Fig. 6. Section of luminal portion of non-pregnant caruncle 18 days after mating. $\times 300$ approx.

Fig. 7. Section of luminal portion of caruncle of ewe 18-days pregnant. The serosal membranes are detached and there is some evidence of epithelial break-down adjacent to the basement membrane overlying the stroma. $\times 300$ approx.

FIG. 8. Section of luminal portion of caruncle of ewe B74 (18-days pregnant) in which stromal breakdown is present. Some lymphocytic infiltration is apparent. $\times 100$ approx.
b binucleate cells
bm basement membrane
cv lumen of chorionic vesicle
1 lymphocyte
$\mathrm{mi}$ cell in mitosis
ms somatic mesoderm

\section{Abbreviations used in plates}

$\begin{array}{ll}\text { p } & \text { pigment cell of uterine stroma } \\ \text { s } & \text { Stäbchen } \\ \text { t } & \text { trophoblast } \\ \text { ue } & \text { uterine epithelial cells } \\ \text { us } & \text { uterine stroma }\end{array}$


PIATE 1

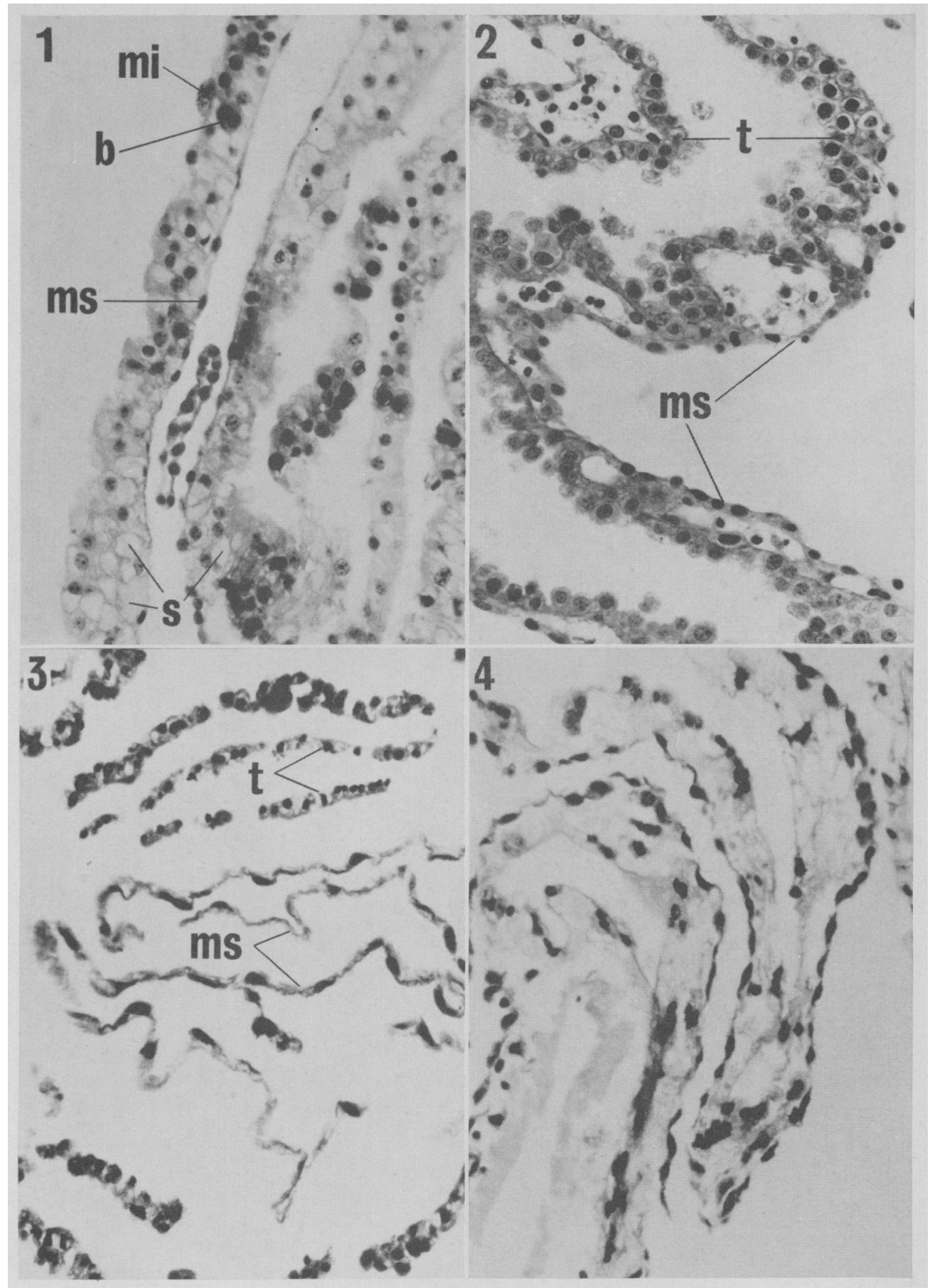

(Facing p. 86) 


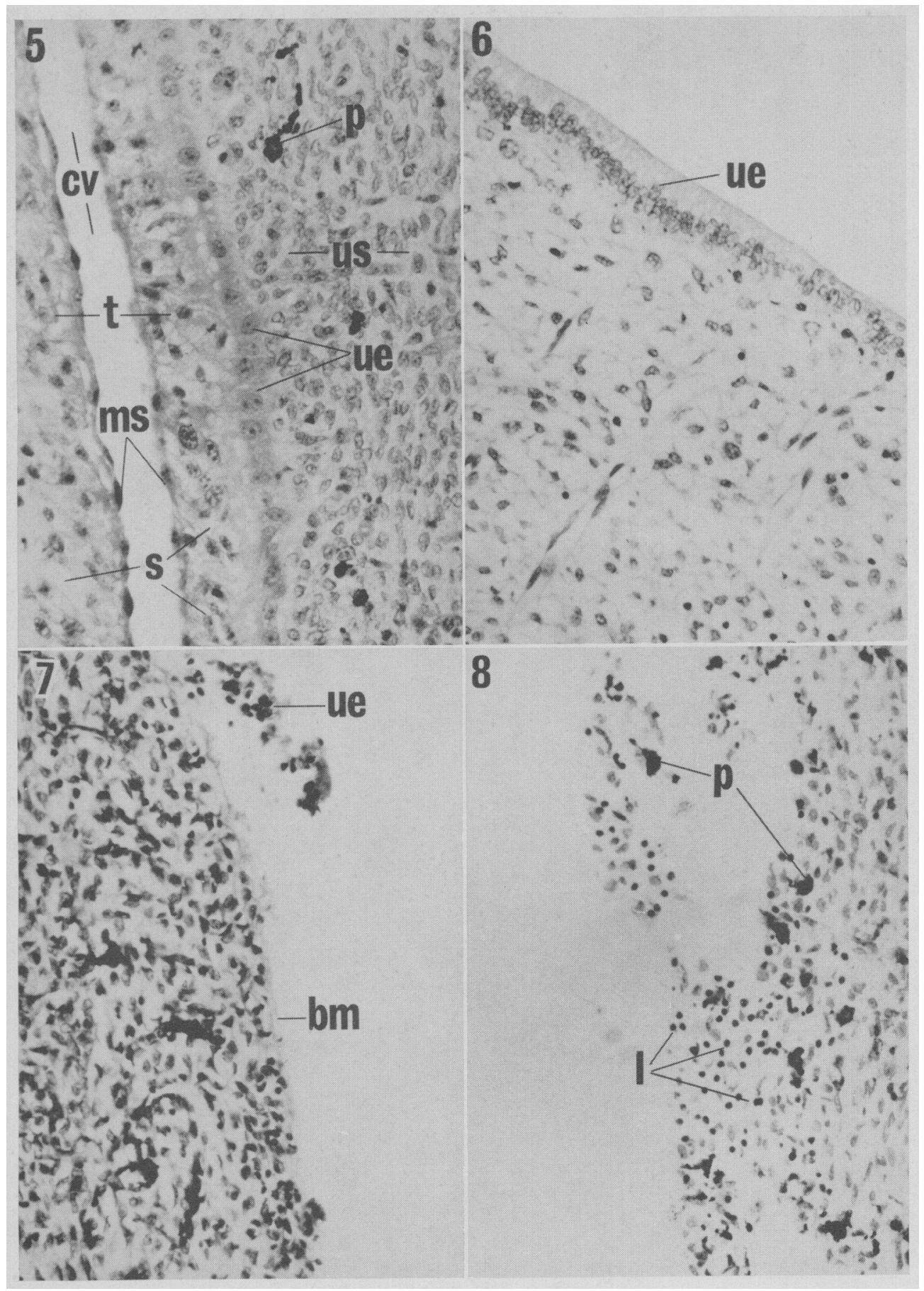

(Facing p. 87) 